\title{
The Man Who Shot Ana Hatherly
}

\author{
Rui Zink ${ }^{1}$ \\ [Article copies available for a fee from The Transformative Studies \\ Institute.E-mail address: journal@transformativestudies.org Website: \\ http://www.transformativestudies.org (C2020 by The Transformative \\ Studies Institute. All rights reserved.] \\ Welcome to the Lab \\ Don't forget the slab \\ [Rocky Horror Picture Show] \\ El misterio es parte de lo divino, y aún de lo sobrenatural. \\ La solución es solo juego de manos. \\ [Mr B., aka the usual suspect]
}

\section{A FAIT-DIVERS}

Stories are pointless unless they are true. So here goes a true story: a few years ago (I could tell the precise date but won't for privacy matters) I shot a famous Portuguese writer. Not one of the many I disdain, envy, or

\footnotetext{
${ }^{1}$ Rui Zink was born in Lisbon in 1961. He's a professor of Editing and Writing at Universidade Nova de Lisboa, as well as a writer and translator, having published more than 30 books. His work is translated in a dozen languages (including French, German, Hebrew, Italian, Romanian, Serbo-Croatian and Japanese), ranging from fiction to plays, from cartoons to opera. He published his first book in 1986, Hotel Lusitano, hailed 25 years later as one of the best novels of his generation with a celebratory edition. In 1990, Rui Zink was a pioneer of writing courses in Portugal. In 1997, he co-authored, with artist António Jorge Gonçalves, the first graphic Portuguese novel: A Arte Suprema. In 2001, he wrote the first Portuguese online novel, Os Surfistas, with the input of e-readers. He wrote a tetralogy about the crisis, comprising O Destino Turístico (2008), A Instalação do Medo (2012), A Metametamorfose e Outras Fermosas Morfoses (2014) and the short novel $O s s O$ (2015). Aside from being a novelist, he is a playwright, writes comic strips, and frequently creates librettos for operas. As a translator, he has brought into Portuguese, among others, Saul Bellow and Richard Zenith. He was visiting scholar at the University of Massachusetts Dartmouth, reader at the University of Michigan and resident writer at Middlebury College, Vermont, USA. Address correspondence to: Rui Zink; e-mail: zink.rui@gmail.com.
} 